\section{Muskmelon and Sweet Corn Production with Legume Cover Crops}

\author{
Harbans L. Bhardwaj ${ }^{1}$ \\ Agricultural Research Station, Box 9061, Virginia State University, \\ Petersburg, VA 23806
}

Addition index words. Austrian winter pea, hairy vetch, white lupin, N fertilizer, sustainable crop production

\begin{abstract}
Winter legume cover crops have been successfully used to meet $\mathrm{N}$ needs of many summer crops, but they are not being used extensively in Virginia and the mid-Atlantic region, especially for specialty crops such as muskmelon and sweet corn. The objective of these studies was to determine the potential of winter legume cover crops in meeting $\mathbf{N}$ needs of muskmelon (Cucumis melo L.) and sweet corn (Zea mays L.). Comparisons of performances of muskmelon and sweet corn, grown after lupin (Lupinus albus L.), hairy vetch (Vicia villosa Roth.), Austrian winter pea ([AWP] Pisum arvense L.), and control fertilized with $112 \mathrm{~kg} \mathrm{~N} \mathrm{ha}^{-1}$, and unfertilized control were made during 1999, 2000, and 2001. The interactions between cover crop treatments and years were, generally, significant. The muskmelon fruit yields were 53.6, 45.0, 23.1, 13.0, and 5.6 $\mathrm{Mg} \cdot \mathrm{ha}^{-1}$ during 1999; 27.8, 26.3, 8.6, 5.8, and 2.2 $\mathrm{Mg} \cdot \mathrm{ha}^{-1}$ during 2000; and 41.1, 39.9, 25.5, 21.4, and $2.1 \mathrm{Mg} \cdot \mathrm{ha}^{-1}$ during 2001 respectively for lupin, hairy vetch, $\mathrm{AWP}, 112 \mathrm{~kg} \mathrm{~N} \mathrm{ha}{ }^{-1}$, and control. Similar results were obtained for number and size of muskmelon fruits. The sweet corn ear yields $\left(\mathrm{Mg} \mathrm{ha}^{-1}\right)$ were 8.5, 5.6, 3.1, 1.5, and 0.7 during 1999; 5.2, 3.9, 4.0, 4.8, and 1.2 during 2000 ; and 2.6, 2.4, 1.9, 2.0, and 0.9 during 2001 , respectively for lupin, hairy vetch, AWP, $112 \mathrm{~kg} \mathrm{~N} \mathrm{ha-1,} \mathrm{and} \mathrm{control.} \mathrm{White} \mathrm{lupin} \mathrm{and} \mathrm{hairy} \mathrm{vetch,} \mathrm{as} \mathrm{winter}$ cover crops, were superior than AWP and $112 \mathrm{~kg} \mathrm{~N} \mathrm{ha}^{-1}$ for sweet corn ear number and size, and plant height. These results demonstrated that winter legume crops, especially lupin and hairy vetch, can be excellent winter cover crops for meeting $N$ needs of muskmelon and sweet corn.
\end{abstract}

The use of inorganic fertilizers, especially $\mathrm{N}$, has been an enigma for modern agriculture. On the one hand, their use has been linked to environmental pollution; on the other hand, they have contributed to yield increases (Drinkwater et al., 1998). Even though animal manures could also pollute the environment, agricultural practices are considered important source of $\mathrm{N}$ pollution of water supplies (EPA, 1992). Estimates of crop absorption of applied $\mathrm{N}$ range from $25 \%$ to $70 \%$ and efficiency decreases with increased fertilizer application (Hills et al., 1983). The unused $\mathrm{N}$ can increase salt content of the soil and production costs (Csizinsky and Schuster, 1982) and can lead to runoff and leaching (Doss et al., 1975), which may contaminate surface and groundwater (Hallberg, 1987; Meisinger et al., 1991; NRC, 1989). In comparison with conventional, high-intensity agricultural methods, organic alternatives, such as the use of legume cover crops, can improve soil fertility and have

Received for publication 14 Mar. 2006. Accepted for publication 27 Apr. 2006. Contribution of Virginia State University, Agricultural Research Station, journal article series no. 250. The use of any trade names or vendors does not imply approval to the exclusion of other products or vendors that may also be suitable.

${ }^{1}$ To whom reprint requests should be addressed. e-mail hbhardwj@vsu.edu fewer detrimental effects on the environment. These alternatives can also produce crop yields equivalent to conventional methods (Tilman, 1998).

The increase in crop yields after a leguminous crop has been reported to be greater than that expected from the estimated quantity of biologically fixed and recycled $\mathrm{N}$ offered by the cover crop (Cook, 1984; Goldstein and Young, 1987; Heichel, 1987; Voss and Shrader, 1984). This is because when cover crops are incorporated in the rotations, they also increase soil moisture; provide partial control of pathogens, insects, and nematodes; and allow more efficient use of leftover nutrients (Cook, 1986). Cardwell (1987) summarized the benefits of including legumes in farming systems as sustained high yield, maintained soil organic matter and fertility, reduced losses resulting from pests, increased water use efficiency in areas of high rainfall, reduced soil erosion, efficient use of labor year-round, and reduced water pollution risk associated with use of inorganic $\mathrm{N}$ fertilizers.

Cover crops have been successfully used to meet nitrogen needs of summer crops - for no-till corn and grain sorghum (Blevins et al., 1990), for corn (Holderbaum et al., 1990), for no-till corn (Decker et al., 1994), for tomatoes (Abdul-Baki and Teasdale, 1993; AbdulBaki et al., 1997; Kelly et al., 1995), for silage corn (Ess et al., 1994), for corn (Stute and Posner (1995), for corn and tomato (Clark et al., 1997, 1999), and for seedless watermelon (Rangappa et al., 2002). Although leguminous cover crops have been shown to be useful in the production of field crops and vegetable crops, they are not being used extensively in Virginia and the midAtlantic region. Given that muskmelon and sweet corn are important crops for Virginia and the mid-Atlantic region, the objective of these studies was to evaluate the potential of legume cover crops in meeting $\mathrm{N}$ needs of succeeding summer crops. Specifically, we were interested in comparing yield and other characteristics of muskmelon and sweet corn when grown after various winter legume cover crops and conventional $\mathrm{N}$ fertilizer use.

\section{Materials and Methods}

This research was conducted for three seasons (1998-1999, 1999-2000, and 2000 2001) at the Randolph Farm of Virginia State University located near Petersburg, Va. (about $37^{\circ} \mathrm{N}$ and $077^{\circ} \mathrm{W}$ ). The soil type at this location was Abell sandy loam (fine loamy, mixed, semiactive, thermic aquic hapridults). During each year, a uniform field was divided into 40 plots, each $\sim 45 \mathrm{~m}^{2}$. Twenty plots were used for muskmelon experiments and the remaining 20 plots were used for sweet corn experiments. For each crop, five winter cover crop treatments were used (lupin, hairy vetch, Austrian winter pea [AWP], $112 \mathrm{~kg} \mathrm{~N} \mathrm{ha}^{-1}$, and a control treatment that did not receive any fertilizer). The Virginia Cooperative Extension recommendations for both muskmelon and sweet corn consist of $\sim 112 \mathrm{~kg} \mathrm{~N} \mathrm{ha}^{-1}$ (VCE, 1997). We used ammonium nitrate (34-0-0) as a broadcast treatment before transplanting muskmelon and planting sweet corn. Even though a split application of $\mathrm{N}$ is recommended for sweet corn production in Virginia, we applied all $\mathrm{N}$ fertilizer in the $112 \mathrm{~kg} \mathrm{~N} \mathrm{ha}^{-1}$ treatment because of the difficulty of mechanically applying a side dress treatment in grown crop. In hindsight, it may have been desirable to split the $\mathrm{N}$ application, especially because of the high leaching potential of ammonium nitrate and because of the sandy soils in our studies.

The experimental design for each crop was a randomized complete block design with four replications. The three cover crops were planted on 5 Oct. 1998, 8 Oct. 1999, and 2 Oct. 2000. The plots of two other treatments stayed fallow throughout the fall, winter, and early spring seasons. The whole experimental areas were sprayed with GRAMOXONE (paraquat: 1,1'-dimethyl-4,4'-bipyridylium dichloride) and ROUNDUP (glyphosate: $\mathrm{N}$-(phosphonomethyl)glycine) herbicides on 3 May 1999, 12 Apr. 2000, and 26 Apr. 2001. The rates used were $1 \mathrm{~L}$ a.i. $\mathrm{ha}^{-1}$ of glyphosate and $500 \mathrm{~g}$ a.i. $\mathrm{ha}^{-1}$ for paraquate plus $1 \%$ volume/volume crop oil. At the time of this burn-down herbicide treatment, the legume cover crops were, generally, in early-bloom stage. In the sweet corn plots, a no-till planter was used to plant AC-8100, a sweet corn hybrid from Abbott and Cobb Seed Company (Feasterville, $\mathrm{Pa}$.), during all 3 years, about 2 
weeks after the herbicide burn-down. The sweet corn plots consisted of multiple rows, spaced $1 \mathrm{~m}$ apart and were $6 \mathrm{~m}$ long. In the muskmelon plots, $\sim 3$-week old seedlings of Athena hybrid from Abbott and Cobb Seed Company, were transplanted in three-row plots spaced $2 \mathrm{~m}$ apart and $3 \mathrm{~m}$ long, about 4 weeks after the herbicide burn-down. In both crops, the weeds were controlled per the recommendations of Virginia Cooperative Extension (VCE, 1997). We used $0.6 \mathrm{~kg}$ a.i. $\mathrm{ha}^{-1}$ of ATRAZINE (2-chloro-4-ethylamino6-isopropylamino-s-triazine) in sweet corn plots as preplant spray treatment for weed control, and $0.7 \mathrm{~kg}$ a.i. $\mathrm{ha}^{-1}$ of CURBIT $3 \mathrm{E}$ (ethalfluralin: ethyl-N-[2-methyl-2-proponyl]-2,6-dinitro-4-[trifluoromethyl]benzenamine)) as a pretransplant spray treatment for weed control in muskmelons. Observations during the season did not indicate any significant weed problems.

During each year, the sweet corn ears were harvested from the middle four rows of each plot and data on ear yield, number of ears, ear size, and plant height were recorded. The sweet corn ears at this stage were considered mature for consumption. The muskmelons were harvested upon maturity on alternate days and data on fruit yield, fruit number, and fruit size were recorded. The muskmelon data from all harvests were combined for statistical analysis.

All data were statistically analyzed by using procedures in SAS (1996). Fisher's protected LSD test was used for mean separation, with a significance level of $5 \%$.

\section{Results and Discussion}

Analysis of variance indicated that significant variation existed among five treatments for performance of muskmelon and sweet corn (Tables 1 and 2). The interactions between treatments and years were significant for muskmelon fruit size (Table 1) and for all traits of sweet corn (Table 2). Given that many year $\times$ treatment interactions were significant, and years, as a source of variation, were also significant, the data were

Table 1. Partial analysis of variance (mean squares) for fruit yield, fruit number, and fruit size for muskmelon grown after legume cover crops during three seasons at Petersburg, Va.

\begin{tabular}{lcccc}
\hline Source & $d f$ & Fruit yield & Fruit number & Fruit size \\
\hline Reps (Years) & 9 & $918.5^{* *}$ & $207,939,308^{* *}$ & $0.20^{* *}$ \\
Years (Y) & 2 & $1102.0^{* *}$ & $417,663,500^{* *}$ & $0.49^{* *}$ \\
Treatments (T) & 4 & $3030.6^{* *}$ & $591,282,173^{* *}$ & $2.00^{* *}$ \\
Y $\times$ T & 8 & 150.4 & $38,347,029$ & $0.16^{* *}$ \\
Error & 36 & 161.6 & $34,006,257$ & 0.05 \\
\hline
\end{tabular}

*,** Significant at $P=0.05$ and 0.01 respectively.

Table 2. Partial analysis of variance for ear yield, ear number, ear size, and plant height for sweet corn grown after legume cover crops during three seasons at Petersburg, Va.

\begin{tabular}{lccllc}
\hline Source & $d f$ & Ear yield & Ear number & Ear size & Plant height \\
\hline Reps, y & 9 & 3.6 & $121,732,467^{*}$ & 0.001 & $328.3^{*}$ \\
Years (Y) & 2 & $24.0^{* *}$ & $129,244,792$ & $0.015^{* *}$ & $6887.7^{* *}$ \\
Treatments (T) & 4 & $32.9^{* *}$ & $268,035,462^{* *}$ & $0.024^{* *}$ & $6155.2^{* *}$ \\
Y $\times$ T & 8 & $9.7^{* *}$ & $454,803,401^{* *}$ & $0.003^{* *}$ & $371.4^{*}$ \\
Error & 36 & 2.0 & $52,829,486$ & 0.001 & 143.9 \\
\hline
\end{tabular}

**** Significant at $P=0.05$ and 0.01 respectively.
The highest mean fresh sweet corn ear yields of $8.5,5.2$, and $2.6 \mathrm{Mg} \mathrm{ha}^{-1}$ were obtained following use of lupin as a cover crop for 1999, 2000, and 2001 respectively (Table 4). During 2 out of the 3 years (2000 and 2001), sweet corn ear yield after hairy vetch was similar to that after lupin, whereas that during 1999 was $\sim 34 \%$ lower than that after lupin. Based on the overall results, we conclude that both lupin and hairy vetch are suitable winter cover crops for a system aiming to eliminate use of $\mathrm{N}$ fertilizers. During all 3 years, lowest ear yield resulted from unfertilized control as expected. However, the ear yields after $112 \mathrm{~kg} \mathrm{~N} \mathrm{ha}^{-1}$ treatment during 2 of the 3 years (1999 and 2001) were significantly lower than those after lupin. Ear yield after hairy vetch during 1999 was also significantly higher than that from $112 \mathrm{~kg} \mathrm{~N} \mathrm{ha}^{-1}$ treatment. During 2000, cover crop and $112 \mathrm{~kg} \mathrm{~N} \mathrm{ha}^{-1}$ treatment were superior than the unfertilized control. Similar results were observed for number of ears, ear size, and plant height. Interestingly, the numbers of ears, after the legume cover crops and those after unfertilized control or $112 \mathrm{~kg} \mathrm{~N}^{-1}$ were not different during 2 of the 3 years (2000 and 2001), but significant differences existed for ear size, indicating that winter legume cover crops were able to meet the needs of sweet corn for production of marketable ears. The sweet corn plant heights after the legume cover crops were generally similar, but superior to those after nonlegume treatments. Based on results with sweet corn, it is concluded that lupin is a suitable winter legume cover crop to support sweet corn production.

Hairy vetch is well-known as an excellent legume cover crop. Extensive research (AbdulBaki et al., 1997; Carrera et al., 2004; Cline and Silvernail, 2001; Shennan, 1992) has demonstrated the positive potential of hairy vetch in meeting $\mathrm{N}$ needs of vegetable crops. However, little is known about the potential of lupin, even though Reeves and colleagues (1990) estimated that lupin can potentially fix 150 to $200 \mathrm{~kg} \mathrm{ha}^{-1} \mathrm{~N}$ for the use of a succeeding crop in the southern United States. The use of lupin as a cover crop in the mid-Atlantic region of the United States is largely unexplored. We are interested in developing white lupin as a food and feed crop in the this area, given that lupin seeds have a high potential as food and feed use. Currently, lupin is being evaluated as an alternative winter grain crop in the mid-Atlantic region of the United States (Bhardwaj et al., 2004). Lupin as a cover crop may have advantage over hairy vetch given that hairy vetch has hard seeds that keep on germinating during the following seasons, and no food or feed use has been identified for hairy vetch. Preliminary research (unpublished) has indicated that a possibility of harvesting lupin as a forage and then harvesting the regrowth for seeds exists. In this unpublished study, depending upon lupin cultivar, regrowth was observed to yield up to $70 \%$ seed yield of uncut lupin. 
Table 3. Mean performance of muskmelon grown after cover crop treatments during 1999, 2000, and 2001 when grown at Petersburg, Va.

\begin{tabular}{|c|c|c|c|}
\hline Treatment & Fruit yield, $\mathrm{Mg} \mathrm{ha}^{-1}$ & Fruits, ha ${ }^{-1}$ & Fruit size, $\mathrm{kg}$ \\
\hline \multicolumn{4}{|l|}{1999} \\
\hline Lupin & $53.6 \mathrm{a}^{\mathrm{z}}$ & $28,472 \mathrm{a}$ & $1.83 \mathrm{a}$ \\
\hline Hairy vetch & $45.0 \mathrm{ab}$ & $2,1806 \mathrm{ab}$ & $1.96 \mathrm{a}$ \\
\hline Austrian winter pea & $23.1 \mathrm{bc}$ & $12,778 \mathrm{bc}$ & $1.30 \mathrm{~b}$ \\
\hline Control with $112 \mathrm{~kg} \mathrm{~N} \mathrm{ha}^{-1}$ & $13.0 \mathrm{c}$ & $10,278 \mathrm{bc}$ & $1.27 \mathrm{~b}$ \\
\hline Unfertilized control & $5.6 \mathrm{c}$ & $5278 \mathrm{c}$ & $0.92 \mathrm{~b}$ \\
\hline \multicolumn{4}{|l|}{2000} \\
\hline Lupin & $27.8 \mathrm{a}$ & $11,667 \mathrm{ab}$ & $2.21 \mathrm{a}$ \\
\hline Hairy Vetch & $26.3 \mathrm{a}$ & $13,194 \mathrm{a}$ & $1.85 \mathrm{~b}$ \\
\hline Austrian winter pea & $8.6 \mathrm{ab}$ & $4861 \mathrm{bc}$ & $1.79 \mathrm{~b}$ \\
\hline Control with $112 \mathrm{~kg} \mathrm{~N} \mathrm{ha}^{-1}$ & $5.8 \mathrm{~b}$ & $3472 \mathrm{bc}$ & $1.70 \mathrm{~b}$ \\
\hline Unfertilized control & $2.2 \mathrm{~b}$ & $1667 \mathrm{c}$ & $1.28 \mathrm{c}$ \\
\hline \multicolumn{4}{|l|}{2001} \\
\hline Lupin & $41.1 \mathrm{a}$ & $20,000 \mathrm{a}$ & $2.04 \mathrm{a}$ \\
\hline Hairy vetch & $39.9 \mathrm{a}$ & $20,417 \mathrm{a}$ & $1.95 \mathrm{ab}$ \\
\hline Austrian winter pea & $25.5 \mathrm{~b}$ & $11,806 \mathrm{~b}$ & $1.79 \mathrm{c}$ \\
\hline Control with $112 \mathrm{~kg} \mathrm{~N} \mathrm{ha}^{-1}$ & $21.4 \mathrm{~b}$ & $14,028 \mathrm{~b}$ & $1.82 \mathrm{bc}$ \\
\hline Unfertilized control & $2.1 \mathrm{c}$ & $2778 \mathrm{c}$ & $0.73 \mathrm{~d}$ \\
\hline
\end{tabular}

Table 4. Mean performance of sweet corn grown after cover crops treatments during 1999, 2000, and 2001 when grown at Petersburg, Va.

\begin{tabular}{|c|c|c|c|c|}
\hline Treatment & Ear yield, $\mathrm{Mg} \mathrm{ha}^{-1}$ & Ears, ha $^{-1}$ & Ear size, $\mathrm{kg}$ & Plant height, $\mathrm{cm}$ \\
\hline \multicolumn{5}{|l|}{1999} \\
\hline Lupin & $8.5 \mathrm{a}^{\mathrm{z}}$ & $43,889 \mathrm{a}$ & $0.19 \mathrm{a}$ & $143.5 \mathrm{ab}$ \\
\hline Hairy vetch & $5.6 \mathrm{~b}$ & $33,889 \mathrm{ab}$ & $0.16 \mathrm{~b}$ & $150.0 \mathrm{a}$ \\
\hline Austrian winter pea & $3.1 \mathrm{bc}$ & $23,333 \mathrm{bc}$ & $0.13 \mathrm{c}$ & $116.5 \mathrm{bc}$ \\
\hline Control with $112 \mathrm{~kg} \mathrm{~N} \mathrm{ha}^{-1}$ & $1.5 \mathrm{c}$ & $13,611 \mathrm{~cd}$ & $0.12 \mathrm{c}$ & $106.3 \mathrm{~cd}$ \\
\hline Unfertilized control & $0.7 \mathrm{c}$ & $6111 \mathrm{~d}$ & $0.11 \mathrm{c}$ & $85.6 \mathrm{~d}$ \\
\hline \multicolumn{5}{|l|}{2000} \\
\hline Lupin & $5.2 \mathrm{a}$ & $31,042 \mathrm{a}$ & $0.17 \mathrm{ab}$ & $101.2 \mathrm{~b}$ \\
\hline Hairy vetch & $3.9 \mathrm{a}$ & $16,042 \mathrm{c}$ & $0.22 \mathrm{a}$ & $126.3 \mathrm{a}$ \\
\hline Austrian winter pea & $4.0 \mathrm{a}$ & $20,417 \mathrm{bc}$ & $0.19 \mathrm{ab}$ & $118.8 \mathrm{a}$ \\
\hline Control with $112 \mathrm{~kg} \mathrm{~N} \mathrm{ha}^{-1}$ & $4.8 \mathrm{a}$ & $32,083 \mathrm{a}$ & $0.15 \mathrm{~b}$ & $84.6 \mathrm{c}$ \\
\hline Unfertilized control & $1.2 \mathrm{~b}$ & $27,188 \mathrm{ab}$ & $0.04 \mathrm{c}$ & $62.4 \mathrm{~d}$ \\
\hline \multicolumn{5}{|l|}{2001} \\
\hline Lupin & $2.6 \mathrm{a}$ & $19,375 \mathrm{c}$ & $0.14 \mathrm{a}$ & $89.4 \mathrm{~b}$ \\
\hline Hairy vetch & $2.4 \mathrm{ab}$ & $17,813 \mathrm{~cd}$ & $0.13 \mathrm{ab}$ & $101.8 \mathrm{a}$ \\
\hline Austrian winter pea & $1.9 \mathrm{c}$ & $16,354 \mathrm{~d}$ & $0.12 \mathrm{~b}$ & $98.3 \mathrm{ab}$ \\
\hline Control with $112 \mathrm{~kg} \mathrm{~N} \mathrm{ha}^{-1}$ & $2.0 \mathrm{bc}$ & $22,500 \mathrm{~b}$ & $0.09 \mathrm{c}$ & $67.4 \mathrm{c}$ \\
\hline Unfertilized control & $0.9 \mathrm{~d}$ & $26,354 \mathrm{a}$ & $0.03 \mathrm{~d}$ & $60.4 \mathrm{c}$ \\
\hline
\end{tabular}

${ }^{\mathrm{z}}$ Means followed by similar letters are not different according to Fisher's protected LSD test $(P=0.05)$.

We did not determine the content and quality of biomass produced by the cover crops. However, in other studies, when 20 lupin lines were grown at three locations in Virginia, yield of above-ground dry matter biomass of lupin varied from 0.3 to $1.7 \mathrm{Mg}$ $\mathrm{ha}^{-1}$ with a mean of $1.3 \mathrm{Mg} \mathrm{ha}^{-1}$ with an average $\mathrm{N}$ content of $2.99 \%$ (unpublished). This led to the addition of $\sim 390 \mathrm{~kg} \mathrm{ha}^{-1} \mathrm{~N}$ as a biomass to the soil in addition to the $\mathrm{N}$ in the rhizosphere resulting from biological $\mathrm{N}$ fixation.

The results from sweet corn are similar to those obtained by Carrera and coworkers (2004), where use of hairy vetch as a cover crop resulted in $43 \%$ greater yield over bare plots. The significant superiority of lupin and hairy vetch cover crops probably resulted from the slow release of $\mathrm{N}$ as a result of mineralization, enhanced water retention, and water availability, as reported by Clark and colleagues (1997) and Sullivan and associates (1991). Results from muskmelon experiments are similar to those reported by Ogbuchiekwe and Griffin (2004) where cowpea [Vigna unguiculata L.(Walp.)] incorporated into the soil resulted in a $\sim 24 \%$ yield
Bhardwaj, H.L., A.A. Hamama, and E. van Santen. 2004. White lupin performance and nutritional value as affected by planting date and row spacing. Agron. J. 96:580-583.

Blevins, R.L., J.H. Herbek, and W.W. Frye. 1990. Legume cover crops as a nitrogen source for no-till corn and grain sorghum. Agron. J. 82(4):769-772.

Cardwell, V. 1987. Grain legumes as components in farming systems, p. 45-58. In: Grain legumes as alternate crops, a symposium sponsored by the Center for Alternative Crops and Products. University of Minnesota, 23-24 July 1987.

Carrera, L.M., A.A. Abdul-Baki, and J.R. Teasdale. 2004. Cover crop management and weed suppression in no-tillage sweet corn production. HortScience 39:1262-1266.

Clark, A.J., A.M. Decker, J.J. Meisinger, and M.S. McIntosh. 1997. Kill date of vetch, rye, and vetch-rye mixture: II. Soil moisture and corn yield. Agron. J. 89:427-434.

Clark, S., K. Klonsky, P. Livingstone, and S. Temple. 1999. Crop yield and economic comparisons of organic, low-input, and conventional farming systems in California's Sacramento Valley. Amer. J. Alt. Agr. 14:109-121.

Cline, G.R. and A.F. Silvernail. 2001. Residual nitrogen and kill date effects on winter cover crop growth and nitrogen content in a vegetable production system. Horttechnology 11:219225.

Cook, R.J. 1984. Root health: Importance and relationship to farming practices, p. 111127. In: D.F. Bezdicek and J.F. Power (eds.) Organic farming: Current technology and its role in sustainable agriculture. Special publication no. 46. Amer. Soc. Agron, Madison, Wis.

Cook, R.J. 1986. Wheat management systems in the Pacific Northwest. Plant Dis. 70:894-898.

Csizinsky, A.A. and D.J. Schuster. 1982. Yield response of staked, fresh-market tomatoes to reduced use of fertilizers and insecticides. J. Amer. Soc. Hort. Sci. 107:648-652.

Decker, A.M., A.J. Clark, J.J. Meisinger, F.R. Mulford, and M.S. McIntosh. 1994. Legume cover crop contributions to no-tillage corn production. Agron. J. 86:126-135.

Doss, D.B., C.E. Evans, and W.A. Johnson. 1975. Rates of nitrogen and irrigation for tomatoes. J. Amer. Soc. Hort. Sci. 100:435-437.

Drinkwater, L.E., P. Wagoner, and M. Sarraantonio. 1998. Legume-based cropping systems have reduced carbon and nitrogen losses. Nature 396:262-265

EPA. 1992. U.S. Environmental Protection Agency. Annual needs survey. USEPA, Office of Water, Washington, D.C.

Ess, D.R., D.H. Vaughn, J.M. Luna, and P.G. Sullivan. 1994. Energy and economic savings from the use of legume cover crops in Virginia corn production. Amer. J. Alt. Agr. 9:178-185.

Goldstein, W.A. and L.D. Young. 1987. An agronomic and economic comparison of a conventional and a low-input cropping system in the Paisleys. Amer. J. Alt. Agr. 2:51-56.

Hallberg, G.R. 1987. Agricultural chemicals in ground water: Extent and implications. Amer. J. Alt. Agr. 2:3-15.

Heichel, G.H. 1987. Legumes as a source of nitrogen in conservation tillage systems, p. 29-35. In: J.F. Power (ed.). The role of legumes in conservation tillage. Soil Conser. Soc. of America, Ankeny, Iowa.

Hills, F.J., F.E. Broadbent, and O.A. Lorenz. 1983. Fertilizer nitrogen utilization by corn, tomatoes, and sugarbeets. Agron. J. 75:423-426.

Holderbaum, J.F., A.M. Decker, J.J. Meisinger F.R. Mumford, and L.R. Vough. 1990. 
Fall- seeded legume cover crops for no-tillage corn in the humid East. Agron. J. 82:117 124.

Kelly, T.C., Y.-C. Lu, A.A. Abdul-Baki, and J.R. Teasdale. 1995. Economics of a hairy vetch mulch system for producing fresh-market tomatoes in the mid-Atlantic region. J. Amer. Soc. Hort. Sci. 120:854-860.

Meisinger, J.J., W.L. Hargrove, R.L. Mikkeelsen, J.R. Williams, and V.W. Benson. 1991. Effects of cover crops on groundwater quality, p. 5768, In: W.L. Hargrove (ed.). Cover crops for clean water. Soil and Water Conservation Soc. Amer., Ankeny, Iowa.

NRC. 1989. Alternative agriculture. National Academy Press, Washington, D.C.

Ogbuchiekwe, E.J. and M.E. Griffin Jr. 2004. Economic return in production of lettuce and cantaloupe is affected by cropping system and management practice. HortScience 39:13211325.

Rangappa, M., A.A. Hamama, and H.L. Bhardwaj. 2002. Legume and grass cover crops for seedless watermelon production. Horttechnology 12:245-249.

Reeves, D.W., J.T. Touchton, and R.C. Kingery. 1990. The use of lupin in sustainable agriculture systems in the Southern Coastal Plain, p. 9. In: Abstracts of technical papers, no. 17. Southern Branch ASA, Feb. 3-7, 1990, Little Rock, AR.

SAS. 1996. SAS system for Windows. SAS Institute, Inc., Cary, N.C.

Shennan, C. 1992. Cover crops, nitrogen cycling, and soil properties in semi-irrigated production systems. HortScience 27:749-754.

Stute, J.K. and J.L. Posner. 1995. Legume cover crops as a nitrogen source for corn in an oat-corn rotation. J. Prod. Agr. 8:385390.

Sullivan, P.G., D.J. Parrish, and J.M. Luna. 1991. Cover crop contribution to $\mathrm{N}$ supply and water conservation in corn production. Amer. J. Alt. Agr. 6:106-113.

Tilman, D. 1998. The greening of green revolution. Nature 396:211-212.

VCE. 1997. Commercial vegetable production recommendations. Publication no. 4576-420. Virginia Coop. Ext. Virginia Tech, Blacksburg, Va.

Voss, R.D. and W.D. Shrader. 1984. Rotation effects and legume sources of nitrogen for corn. p. 61-68. In: D.F. Bezdicek and J.F. Power (eds.). Organic farming: Current technology and its role in sustainable agriculture. Special publication no. 46. Amer. Soc. Agron, Madison, Wis. 